\title{
Post-harvest treatment of algerian broad beans using two different solar drying methods
}

\author{
Chouicha, S.; Boubekri, A.*; Berbeuh, M. H.; Mennouche, D.; Frihi, I.; Rzezga, A. \\ Université Kasdi Merbah Ouargla, Laboratoire de développement des Energies Nouvelles et \\ Renouvelables dans les Zones Arides et sahariennes, Faculté des Sciences Appliquées, Ouargla \\ 30000 Algeria
}

*E-mail of the corresponding author: boubekri.abdelghani@univ-ouargla.dz

\begin{abstract}
This work was carried up in the objective to valorize the broad beans, largely harvested in Algeria, by solar drying means. In the present research paper, an experimental study was conducted on solar drying of broad beans by two different methods. Experimental trials were performed on a direct and an indirect laboratory scale solar dryers at Ouargla university in the southern of Algeria. Selected samples were dried at $50^{\circ} \mathrm{C}, 55^{\circ} \mathrm{C}, 60^{\circ} \mathrm{C}$ and $65^{\circ} \mathrm{C}$. In both two applied cases, drying curves were obtained and compared. Among twelve consulted drying models the Page model was correlated with satisfaction to describe the solar drying of broad beans using a non linear regression analysis method. Operating and thermal performances of the two used drying systems were checked by the energy effeceincy and economic calculation. Obtained results showed that the direct solar drying ensures good preservation of the final product with a drying time of 5 hours.
\end{abstract}

Keywords: solar drying ; convective drying ; broad bean ; quality 


\section{Introduction}

Faba bean (Vicia faba L.) is one of the oldest crops and ranks the sixth in production among the different legumes grown in the world after soybean, peanut, beans, peas, and chickpeas. Faba bean is popular legume food with high yield capacity and high nutritional value. It is widely used in the Mediterranean region as source of protein in both human and animal nutrition. It is a popular breakfast food and also used as vegetable green or fresh canned. In Algeria, faba bean is one of the most important pulse crop cultivated due to the richness of seed protein content. Also, The most important organic components of faba bean seeds are proteins $20-41 \%$ of seed dry matter, carbohydrates (51-68\% ), 12\% fiber, $1.2-4 \%$ lipids vitamins and minerals [1]. Due to its chemical composition, fava bean is a suitable food for diabetics and may help prevent heart disease and reduce levels of blood glucose vitamins and minerals [2]. The major producer countries include China, Indonesia, India, Turkey, Egypt, Spain, France and Algeria. Broad beans is grown on 12,000 ha areas in Algeria, with a production of 60,787 tons in 2013 [3]. Due to their seasonal and perishable nature, broad beans must be subjected to some form of preservation such as canning, freezing, or cold storage in order to make them available for later consumption [4]. Drying is practiced to enhance the storage life, to minimize losses during storage, and to reduce transportation costs of agricultural products [5]. Solar drying of agricultural products is one of the most important potential applications in the Algerian Sahara. Farmers and citizens dry crops particularly menthe, tomato, abricots, and broad beans. Traditional open sun drying is practiced on a large scale in Ouargla regions where the agriculture suffers from high product losses due to inadequate drying, fungal growth, encroachment of insects, birds and rodents, etc. The problems associated with open-air drying can be solved through the use of a solar dryer which can reduce crop losses and improve the quality of dried product significantly compared to traditional drying method. Solar dryers used in agriculture for food and crop drying are used for industrial drying processes. They can be proved to be a very useful device from the energy conservation point of view. Such a process not only saves energy but also saves a lot of time, occupies less area, improves quality of the product, makes the process more efficient, and also protects the environment [6]. A research group in the laboratory of renewable energy in aride zones (LENREZA) at Ouargla University, Algeria, worked in this field of solar drying. Two types of solar dryer: indirect hybrid solar dryer and direct active solar dryer have been constructed and tested in Ouargla climatic conditions. In the direct solar dryer the product to be dried receives energy from both direct exposure to solar radiation; also the product being dried is protected from rain, insects, and dust. They found the product to have high-quality in terms of flavor, color, and texture. In all cases, the use of a direct convective solar dryer considerably reduces drying time in comparison to open-sun drying. The Passive solar dryers have the advantage of cheap, easy construction from locally available materials and 
do not require any other energy during operation. Their major drawbacks are the decrease drying rates, important drying time and the very high internal temperature with the likelihood of overheating the product [7, 8]. Various drying techniques are employed to dry different food products. Each technique has its own advantages and limitations. Choosing the right drying techniques is thus important in the process of drying of the perishable products. To reduce its dependence on solar radiation for operation and to improve the quality of drying many studies on drying of fruits and vegetables using solar dryers with different sizes and designs exist in literature [9]. We can refer to some works such as on drying of potato [10], green pepper, green bean and squash[11], apricot [12], pistachio, and other products. However, studies on drying of broad beans are scarce. Therefore, the analyze of chemical composition and improving of production were experimentally investigated [13-16]. No information is available on the drying behavior of broad beans in the open literature. Therefore the main objectives of this study are to investigate the valorization by drying of broad beans for both direct and indirect solar drying conditions, and to study the thin layer drying modeling of broad beans.

\section{Materials and Methods}

Fresh local broad beans (Faba vicia l) were bought at local market in Ouargla, Algeria. They were singled out one by one using a visual criterion like color, size, absence of physical damage and uniform maturation degree. Dry pods were removed manually by visual inspection. The broad beans pods were then shelled manually.

\subsection{Description of the Drying System}

Two different solar driers were used in this study (Fig. $1 \mathrm{a}, \mathrm{b}$ ). They are both laboratory scale prototypes, suitable for the agroalimentary products, designed and assembled by the energy conversion research unit at LENREZA laboratory, University of Ouargla, Algeria. The direct forced convective dryer (fig. 1a) consists mainly of a drying room and a chimney. The indirect forced convective drier system (fig. 1b) is composed of solar collector with simple circulation inclined by $31^{\circ} \mathrm{C}$ (Ouargla city altitude, Algeria). Air circulation and air exit are aspired by a fan (trade mark KFA-30 A; at a speed of 1400 rotation $/ \mathrm{mn})$.

\subsection{Moisture Measurements}

Moisture was determined with a kern moisture analyzer operating at the following conditions: sample weight $(45 \mathrm{~g})$, analysis temperature $\left(105^{\circ} \mathrm{C}\right)$. The device stops automatically once weight of dehydrated sample is constant. Moisture content is expressed as a percentage value. Three measurements were taken, and the mean value of relative moisture is $2.2 \% \pm 0.1$ in dried base. During the experiments, broad beans were dried to the final moisture content of $0.13 \mathrm{~kg}$ water / kg dry matter [17] 

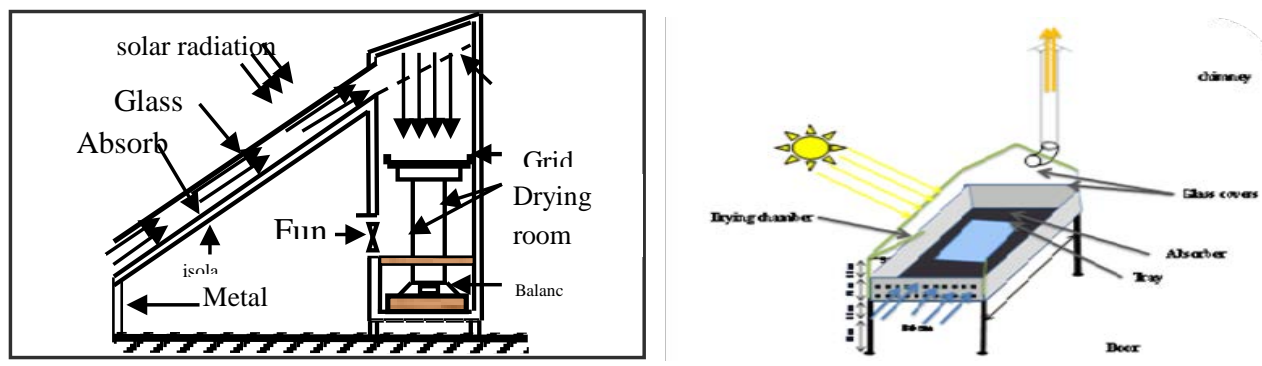

Fig. 1 Schematic diagrams of an indirect active hybrid solar-electrical dryer and a direct solar dryer.

\subsection{Experimental Procedure and Measures}

Prior to each experiment, the product samples were weighed with a pricision of $0.01 \mathrm{~g}$ then reweighed at equal time intervals. So the check in was done each 60 minutes. The desired final moisture content were defined as the standard moisture ensuring a suitable storage of the vegetable product wich is about $0.13 \mathrm{~kg}$ water $/ \mathrm{kg}$ dry matter [4]. The experiment is stopped when the desired final water content is reached.

\section{Mathematical Modeling of Drying Kinetics}

Experimental results of moisture ratio versus drying time were adapted to the theoretical semi models most significant, largely widespread in the process of drying. The report/ratio of moisture (MR) and the drying rate of broad beans during the experiments of drying were calculated using the following equations:[18,19]

$$
\begin{aligned}
M R & =\frac{X-X_{e}}{X_{0}-X_{e}} \\
\frac{d X}{d t} & =\frac{X_{t+\Delta t}-X_{t}}{\Delta t}
\end{aligned}
$$

\subsection{Data Analysis}

The coefficient of determination $\left(\mathrm{R}^{2}\right)$, reduced chi-square $\left(\chi^{2}\right)$, and root mean square error (RMSE) were used in this study to evaluate the goodness of fit. To get the best fit of the experimental data, the coefficient of determination $\mathrm{R}^{2}$ should be higher and the $\chi^{2}$ lower. 
Table 1. Empirical models of drying

\begin{tabular}{|c|c|c|c|}
\hline $\mathbf{N}^{\circ}$ & Model equation & Name & References \\
\hline 01 & $X R(t)=\exp (-k t)$ & Newton & O’callghan et al (1971) \\
\hline 02 & $X R(t)=\exp \left(-k t^{n}\right)$ & Page & Page (1948) \\
\hline 03 & $X R(t)=\exp (-k t)$ & Page modified & Overhults et al (1973) \\
\hline 04 & $X R(t)=A \exp (-k t)$ & Henderson et Pabis & Hunderson and pabis (1969) \\
\hline 05 & $X R(t)=A \exp (-k t)+B$ & Logarithmique & Yagciolu et al (1999) \\
\hline 06 & $\begin{array}{l}X R(t)=A_{1} \exp .\left(-k_{1} t\right)+A_{2} \exp . \\
\left(-k_{2} t\right)\end{array}$ & Two terms & Sharefeldeen et al (1980) \\
\hline 07 & $X R(t)=1+A_{1} t+A_{2} t^{2}$ & Wang et Singh & Wang and singh (1978) \\
\hline 08 & $\begin{array}{l}X R(t)=A \exp .(-k t)+(1-A) \\
\exp .(-k b t)\end{array}$ & Diffusional Approach & Sharef eldeen et al (1979) \\
\hline 09 & $\begin{array}{l}X R(t)=A \exp .\left(-k_{1} t\right)+(1-A) \exp . \\
\left(-k_{2} t\right)\end{array}$ & Verma & Verma et al (1979) \\
\hline 10 & $\begin{array}{l}X R(t)=A_{1} \exp .\left(-k_{1} t\right)+A_{2} \exp . \\
\left(-k_{2} t\right)+A_{3} \exp .\left(-k_{3} t\right)\end{array}$ & $\begin{array}{l}\text { Henderson et Pabis } \\
\text { modified }\end{array}$ & Kara thano (1999) \\
\hline 11 & $\begin{array}{l}X R(t)=A \exp .(-k t)+(1-A) \\
\exp .(-A k t)\end{array}$ & $\begin{array}{l}\text { Two terms } \\
\text { exponential }\end{array}$ & Sharef eldeen et al (1980) \\
\hline 12 & $X R(t)=A_{1} \exp \left(-k t^{n}\right)+A_{2} t$ & Midilli et autres & Diamante and murno (1991) \\
\hline
\end{tabular}

\section{Results and Discussion}

\subsection{Drying behavior as influenced by the dryer type}

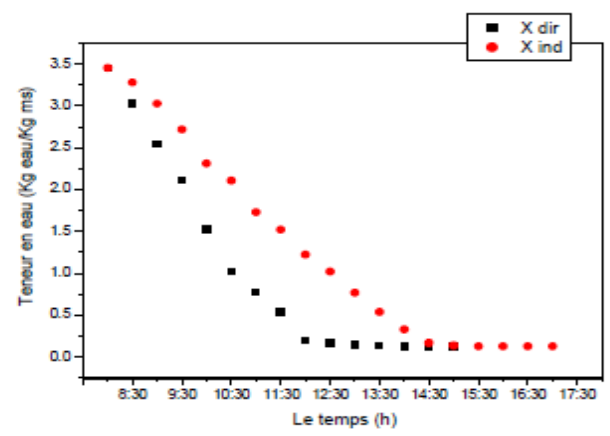

Fig. 2 Moisture content evolution versus time

Figure 2 presents the variation in the moisture content as a function of time in the types of driers direct and indirect, it is clear that the moisture content decrease continuously with drying time, the type of solar dryer affected drying time and product quality. The drying time taken to reduce moisture content from $2.2 \pm 0.1 \mathrm{~kg}$ water $/ \mathrm{kg} \mathrm{dm}$ to final moisture of $0.13 \pm 0.1 \mathrm{~kg}$ water $/ \mathrm{kg} \mathrm{dm}$ was $5 \mathrm{~h}$ for the direct solar dryer and $8 \mathrm{~h}$ for the indirect one. Obtained experimental results proved the importance of the direct process in the 
valorization of the product compared to the indirect one. In reference to available literature, it is also evident that both the two tested methods are more efficient than the sun drying method traditionally adopted by farmers.

\subsection{Suitable Model for Describing Drying Process}

\subsubsection{Models and Statistical Criteria}

By using of Curve-Expert software, it was noted that the values of the three used statistical criteria (standard error (S), coeff. Correlation (r), and Chi Square) appear very similar, making it difficult to distinguish between 12 models. According to the calculation results we saw that for the Page model, the minimum value of the standard error $S=0.000819$, the correlation coefficient $\mathrm{R}$ corresponds to a large value $\mathrm{R}=0.999848$, with a minimum value of Chi square $=0.010008$ so the empirical page model describes solar drying of broad beans

\subsubsection{Expression of the Page Model Parameters as a function of Temperature}

The following results were obtained by curve fitting using the curve-Expert1.3 software for each parameter. The empirical relation found between the parameters of the equation of page model and temperature are developed and are plotted in Fig3.
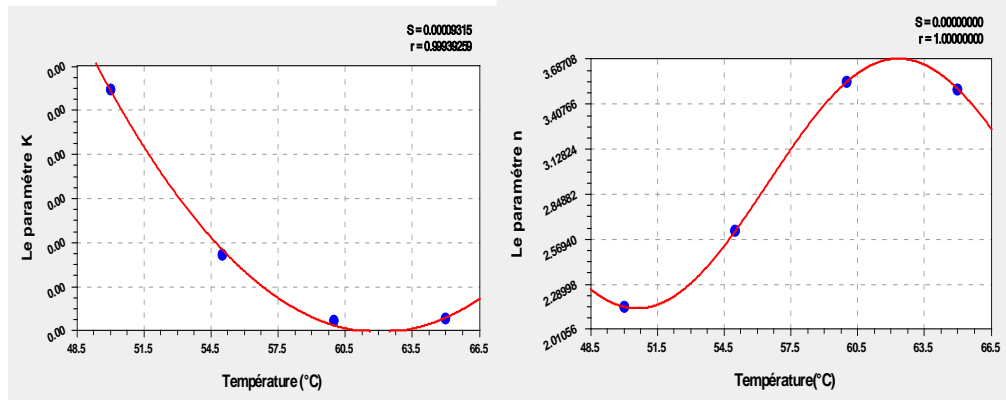

Fig 3. Evolution of $K$ and $n$ parameters with temperature

Finally the expressions adopted for the general equation according to the Page model with the parameters depending from time and temperature of the drying air, are given below.

$$
\begin{aligned}
& X R(t)=\exp .\left(-k t^{n}\right) \\
& n(T)=2.916086+0.775023 * \cos (0.267699 T-4.114475) \\
& K(T)=0.091139+0.002939 T+2.369690 e-005 T
\end{aligned}
$$

\section{Conclusion}

In this study, post harvest treatment of broad beans, by hot air direct and indirect solar drying means, is presented. Based on the experimental results reported herein, the following conclusions can be made. Solar drying has allowed us to minimize post-harvest losses, and preserve the final quality of the dried product, especially when the search aims the 
conservation for a long term. Experimental results showed that broad beans dried in direct solar drier had shorter drying time than other dried in indirect convective solar dryer. The semi theoretical models, namely, Page model was used to describe the drying kinetics of broad beans with a satisfactory correlation. An empirical equation, with temperature dependent parameters, was successfully adopted. The most adaptable solar dryer for drying of the broad beans is the direct solar dryer. Although this adaptation depends on technoeconomic parameters and social considerations. The criteria for energy consumption and profit on the cost led to place the direct solar dryer as more efficient and more profitable economically.

\section{References}

[1] M.H. Hendawey, A.M.A. Younes. Biochemical evaluation of some faba bean cultivars under rainfed conditions at El-Sheikh Zuwayid. Annals of Agricultural Sciences Volume 58, Issue 2, December 2013, Pages 183-193

[2] Cecilia Baginsky, Álvaro Peña-Neira, Alejandro Cáceres, Teresa Hernández, Isabel Estrella, Héctor Morales, Ricardo Pertuzé, Phenolic compound composition in immature seeds of fava bean (Vicia faba L.) varieties cultivated in Chile Journal ofFood Composition and Analysis Volume 31, Issue 1, August 2013, Pages 1-6

[3] Food and Agriculture Organization. Agriculture data, 2012. Available at: http://faostat.fao.org/site/567/DesktopDefault.aspx?PageID $=$ 567\#ancor (accessed July 23, 2012).

[4] İbrahim Doymaz, Fergun Kocayigit, Drying and Rehydration Behaviors of Convection Drying of Green Peas journal of Drying Technology . Drying Technology, 29: 12731282, 2011

[5] Pallav Purohit, Atul Kumar, Tara Chandra Kandpal. Solar drying vs. open sun drying: A framework for financial evaluation Solar Energy 80 (2006) 1568-1579

[6] S. Boughali, H. Benmoussa, B. Bouchekima, D. Mennouche, H. Bouguettaia, D. Bechki, Crop drying by indirect active hybrid solar - Electrical dryer in the eastern Algerian Septentrional Sahara. Solar Energy 83 (2009) 2223-2232

[7] S. VijayaVenkataRamana, S. Iniyanb, Ranko Goicc. A review of solar drying technologies. Renewable and Sustainable Energy Reviews 16 (2012) 2652- 2670

[8] Dilip Jain , Rajeev Kumar Jain. Performance evaluation of an inclined multi-pass solar air heater with in-built thermal storage on deep-bed drying application Journal of Food Engineering 65(2004) 497-509 
[9] Tadahmun A. Yassen, Hussain H. Al-Kayiem. Experimental investigation and evaluation of hybrid solar/thermal dryer combined with supplementary recovery dryer. Solar Energy 134 (2016) 284-293

[10] Seyfi Şevik Experimental investigation of a new design solar-heat pump dryer under the different climatic conditions and drying behavior of selected products. Solar Energy Volume 105, July 2014, Pages 190-205

[11]Akpinar, E., Midilli, A., Bicer, Y., 2003. Single layer drying behaviour of potato slices in a convective cyclone dryer and mathematical modelling. Energy Convers. Manage. 44, 1689-1705.

[12]Yaldiz, O., Ertekin, C., 2001. Thin layer solar drying of some vegetables. Drying Technol. 19, 583-596.

[13]Serpil Sahin, Gulum Sumnu, Ferihan Tunaboyu Usage of solar assisted spouted bed drier in drying of pea food and bioproducts processing 91 (2013) 271-278

[14]Guillermo Petzold, Marisa Caro, Jorge Moreno, Influence of blanching, freezing and frozen storage on physicochemical properties of broad beans (Vicia faba L) International Journal of Refrigeration Volume 40, April 2014, Pages 429-434

[15] S.K. Sathe Beans: Overview Encyclopedia of Food Grains (Second Edition) 2016, Pages 297-306 Volume 1: The World of food Grains

[16] Marçal Plans, Joan Simó, Francesc Casañas, Roser Romero del Castillo, Luis E. Rodriguez-Saona, José Sabaté, Estimating sensory properties of common beans (Phaseolus vulgaris L.) by near infrared spectroscopy, Food Research International, Volume 56, February 2014, Pages 55-62

[17] Lijiao Kan, Shaoping Nie, Jielun Hu, Sunan Wang, Steve W. Cui, Yawen Li, Sifan $\mathrm{Xu}$, Yue Wu, Junqiao Wang, Zhouya Bai, Mingyong Xie, Nutrients, phytochemicals and antioxidant activities of 26 kidney bean cultivars, Food and Chemical Toxicology 